\title{
Genomic and phylogenetic evidence that Maize rough dwarf and Rice black-streaked dwarf fijiviruses should be classified as different geographic strains of a single species
}

\author{
L. XIE, M.-F. LV, J. YANG, J.-P. CHEN*, H.-M. ZHANG*
}

\begin{abstract}
State Key Laboratory Breeding Base for Zhejiang Sustainable Pest and Disease Control (Key Laboratory of Plant Protection and Biotechnology, Ministry of Agriculture / Zhejiang Provincial Key Laboratory of Plant Virology), Institute of Virology and Biotechnology, Zhejiang Academy of Agricultural Sciences, Hangzhou 310021, P. R. China
\end{abstract}

\begin{abstract}
Summary. - Maize rough dwarf disease (MRDD) has long been known as one of the most devastating viral diseases of maize worldwide and is caused by single or complex infection by four fijiviruses: Maize rough dwarf virus (MRDV) in Europe and the Middle East, Mal de Rio Cuarto virus (MRCV) in South America, rice blackstreaked dwarf virus (RBSDV), and Southern rice black-streaked dwarf virus (SRBSDV or Rice black-streaked dwarf virus 2, RBSDV-2) in East Asia. These are currently classified as four distinct species in the genus Fijivirus, family Reoviridae, but their taxonomic status has been questioned. To help resolve this, the nucleotide sequences of the ten genomic segments of an Italian isolate of MRDV have been determined, providing the first complete genomic sequence of this virus. Its genome has 29144 nucleotides and is similar in organization to those of RBSDV, SRBSDV, and MRCV. The 13 ORFs always share highest identities (81.3-97.2\%) with the corresponding ORFs of RBSDV and phylogenetic analyses of the different genome segments and ORFs all confirm that MRDV clusters most closely with RBSDV and that MRCV and SRBSDV are slightly more distantly related. The results suggest that MRDV and RBSDV should be classified as different geographic strains of the same virus species and we suggest the name cereal black-streaked dwarf fijivirus (CBSDV) for consideration.
\end{abstract}

Keywords: Maize rough dwarf virus (MRDV); Rice black-streaked dwarf virus (RBSDV); Fijivirus; Cereal black-streaked dwarf fijivirus (CBSDV)

\section{Introduction}

Maize (Zea mays L.) is one of the most important food, forage, and energy crop plants in the world but a variety of viral diseases cause significant agronomic losses each year

${ }^{*}$ Corresponding authors. E-mail: zhhengmu@tsinghua.org.cn; jpchen2001@yahoo.com.cn; phone: +86-571-8641-6056; +86571-8640-4003.

Abbreviations: FDV = Fiji disease virus; GDV = Garlic dwarf virus; ICTV = International Committee on Taxonomy of Viruses; $\mathrm{MRDD}=$ Maize rough dwarf disease; $\mathrm{MRDV}=\mathrm{MRD}$ virus; $\mathrm{MRCV}=\mathrm{Mal}$ de Rio Cuarto virus; NLRV = Nilaparvata lugens reovirus; OSDV = Oat sterile dwarf virus; RBSDV-2 = Rice blackstreaked dwarf virus 2; SRBSDV = Southern rice black-streaked dwarf virus
(Ali and Yan, 2012). Maize rough dwarf disease (MRDD) is one of the most destructive viral diseases worldwide and has threatened crop production and food supplies in maizegrowing regions of the world in recent years (Lenardon et al., 1998, 2001; Zhang et al., 2001b, 2008; Dovas et al., 2004; Hoang et al., 2011; Achon et al., 2013, 2015; Ortiz et al., 2014). Diseased maize plants are typically stunted with white waxy swellings or enations along the veins on the abaxial surfaces of the sheath and underside of the leaf blade, malformed tassels, and poor or no ears (or nubbins), thus resulting in substantial yield losses (Boccardo and Milne, 1984). MRDD is caused by single or complex infections of four viruses, including Maize rough dwarf virus (MRDV), Mal de Rio Cuarto virus (MRCV), Rice black-streaked dwarf virus (RBSDV), and Southern Rice black-streaked dwarf 
virus (SRBSDV) (also known as Rice black-streaked dwarf virus 2 (RBSDV-2)) (Zhang et al., 2001a,b; 2008; Zhou et al., 2008; Wu et al., 2013). These four viruses together with the little-studied Pangola stunt virus (PaSV), form group 2 of the genus Fijivirus, the family Reoviridae, based on insect vector specificity, plant hosts, and serological and nucleotide sequence similarities (Attoui et al., 2012). The other groups (Groups 1 and 3-5) each have a single member, respectively, Fiji disease virus (FDV), Oat sterile dwarf virus (OSDV), Garlic dwarf virus (GDV) and Nilaparvata lugens reovirus (NLRV) (Attoui et al., 2012). All known fijiviruses contain ten linear genomic segments of double-stranded RNA (dsRNA), ranging in size from approximately 1.4 to $4.5 \mathrm{~kb}$ and named S1-10 according to their migration in PAGE, and most of them replicate in their plant hosts, where they induce growth abnormalities. Previous extensive studies have shown that the four viral pathogens of MRDD are closely related to each other and similar in particle morphology, genomic profile, and serological relationships (Luisoni et al., 1973; Milne et al., 1973, 1977a,b; Reddy et al., 1975, 1983; Isogai et al., 1995; Zhang et al., 2001a,b; Distéfano et al., 2002, 2003, 2005, 2009; Guzmán et al., 2007, Wang et al., 2010). All these viruses naturally infect maize and cause similar symptoms on maize or other host plants (Milne et al., 1977a; Attoui et al., 2012).

There have been suggestions that these four viruses should be considered as geographical races of same species (Azuhata et al., 1993), but there are some clear differences: (1) There are no reports that MRDV (in Europe) or MRCV (in Argentina) can naturally infect rice, whereas RBSDV and SRBSDV can be found naturally occurring on both rice and maize in China, Japan, Korea, and Vietnam (Milne et al., 1977a; Boccardo and Milne, 1984; Lenardon et al., 1998; Zhang et al., 2001b, 2008; Distéfano et al., 2003; Zhou et al., 2008; Hoang et al., 2011; Yin et al., 2011; Achon et al., 2013; Matsukura et al., 2013; Ortiz et al., 2014). (2) MRDV and RBSDV are transmitted almost exclusively by the planthopper, Laodelphax striatellus Fallén, whereas SRBSDV is transmitted by the white-backed planthopper (Sogatella furcifera Horváth) and MRCV by the planthopper Delphacodes kuscheli Fennah. (3) MRDV is transmitted through the eggs of its vector insect but RBSDV is not (Harpaz and Klein 1969; Harpaz, 1972; Milne et al., 1977a). (4) Serological comparisons and hybridization experiments using cDNA probes also suggest that they are distinct viruses (Isogai et al., 1995; Marzachi et al., 1995). (5) The complete genomes of at least one isolate of MRCV, RBSDV, and SRBSDV have been determined and comparisons support the view that these three fijiviruses, at least, should continue to be members of distinct species (Zhang et al., 2001a; Guzmán et al., 2007; Wang et al., 2010; Xue et al., 2014). This view is reflected in the latest taxonomy (Attoui et al., 2012).
MRDV was first described in Italy in the late 1940s (Boccardo and Milne, 1984) and now causes a severe and economically important disease in several European and Mediterranean countries (Boccardo and Milne, 1984; Dovas et al., 2004; Achon et al., 2013; 2015). However, although Maize rough dwarf virus is recognised as an independent species in the latest ICTV report (Attoui et al., 2012), there has been only limited sequence data to help inform debates about its taxonomic status (Marzachi et al., 1991; 1995; Azuhata et al., 1993). We now report the complete sequence of an Italian isolate of MRDV and genomic comparisons indicating that MRDV and RBSDV can best be classified within a single virus species.

\section{Materials and Methods}

Plant materials. Infected maize plants with typical symptoms were generously provided by Dr. Piero Caciagli, Istituto di Virologia Vegetale - CNR, Torino, Italy, in July 2008. Infected leaves were frozen and stored at $-80^{\circ} \mathrm{C}$ until use.

Extraction and purification of viral genomic dsRNA. The viral genomic double-stranded RNAs were extracted directly from infected maize plants as previously described (Uyeda et al., 1998; Zhang et al., 2007a, b). In brief, total nucleic acids were extracted with phenol-chloroform and then ethanol-precipitated. After treatment with DNase I ( TaKaRa) and RNase A (Boehringer Mannnheim), the dsRNAs were further purified with CC41 cellulose powder (Whatman). The genomic dsRNA segments were then separated on polyacrylamide gels, individual bands were excised from the gel, dissolved in 2-mercaptoethanol (2-ME) and further purified from the solubilized fractions by specific adsorption on CC41 cellulose powder as previously described by Dulieu and Bar-Joseph (1989).

Construction and sequencing of viral cDNA library. The purified genomic dsRNAs were suspended in $30 \mu \mathrm{l}$ of $\mathrm{H}_{2} \mathrm{O}$ and then denatured by adding $20 \mu \mathrm{DMSO}$ (dimethyl sulfoxide), incubating at $95^{\circ} \mathrm{C}$ for $5 \mathrm{~min}$ and quickly transferring to ice for $10 \mathrm{~min}$. The denatured dsRNA was precipitated with 3 volumes of ethanol and $1 / 10$ volume of sodium acetate, $\mathrm{pH} 5.2$ and used for cDNA synthesis. cDNA libraries were constructed essentially as described previously (Zhang et al., 2001a, 2007a) with minor modifications. In brief, each purified genomic segment was denatured and used as a template for first-strand cDNA synthesis by Superscript Reverse Transcriptase (MBI) in the presence of $100 \mathrm{ng}$ of 9-nucleotide random primers. After incubation at $42^{\circ} \mathrm{C}$ for $60 \mathrm{~min}$, the reaction was stopped by heating at $70^{\circ} \mathrm{C}$ for $15 \mathrm{~min}$, and the mixture was placed onto ice for $3 \mathrm{~min}$. Thereafter, $1 \mu \mathrm{l}$ of RNase $\mathrm{H}(2 \mathrm{U})$ was added, and the mixture was incubated at $37^{\circ} \mathrm{C}$ for $20 \mathrm{~min}$. The resulting cDNA was purified using the PCR Gel Extraction Kit (QIAGEN), and then annealed at $65^{\circ} \mathrm{C}$ and repaired using exTaq DNA polymerase (TaKaRa). It was then purified using the PCR Gel Extraction Kit (QIAGEN), and finally ligated into pGEM T easy vector (Promega), and transformed 
into competent Eschrichia coli TG1 cells for cloning. The recombinant plasmid DNAs were isolated by the alkaline lysis method or using the QIAprep spin mini prep kit (Qiagen Ltd., Crawley, UK) and analyzed by agarose gel electrophoresis (Sambrook et al., 1989), and the clones for each of the genomic segments containing insertions of more than $200 \mathrm{bp}$ were used for sequencing on an ABI Prism 3730 DNA sequencer (PerkinElmer Applied Biosystems) with the BigDye Terminator v3.1 cycle sequencing kit according to the manufacturer's instructions.

Sequence assembly, validation and analysis. Sequences of each genomic segment were assembled using the DNAman version 6.0 program (Lynnon Corporation, Canada). On the basis of assembled contigs, the internal and terminal sequences of each genomic segment were amplified by RT-PCR or ligation RT-PCR as previously described (Zhang et al., 2007a, b) and were purified using a PCR Gel Extraction Kit (QIAGEN) for validation by sequencing as above. Searches for protein homology were performed with the BLAST program (Altschul et al., 1997). Other related viral sequences were downloaded from EMBL/NCBI/DDBJ databases and aligned using ClustalW, version 2.0 (Thompson et al., 1994). Phylogenetic and molecular evolutionary analyses were done using MEGA version 6.0 (Tamura et al., 2007).

\section{Results}

\section{Genomic profile and organization}

The viral dsRNAs of an Italian MRDV isolate were extracted from infected maize leaves and then analyzed on a $12.5 \%$ polyacrylamide gel overnight, which yielded ten independent bands that were named S1-10 according to their migration in PAGE (Fig. 1). Individual dsRNA bands

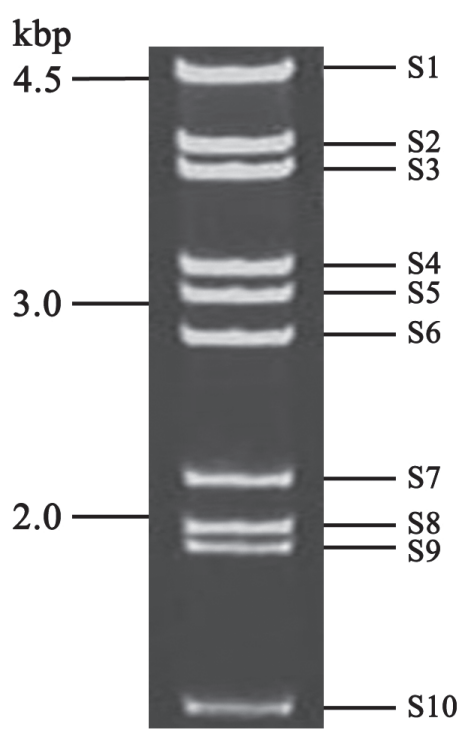

Fig. 1

Ten genomic segments of MRDV on polyacrylamide gel electrophoresis (PAGE)

Approximate sizes (kbp) are shown on the left.

were excised from the gel and used to construct cDNA libraries for sequencing. The full-length sequences of each genomic segment have been determined and deposited in the GenBank/EMBL/DDBJ databases with the accession numbers HQ637550-HQ637559. The chief characteristics of the segments are shown in Table 1 . The total ten-segment genome of MRDV comprised of 29144 nucleotides (nt), 3 nt longer than the RBSDV genome, making it the largest

Table 1. Summary of the genomic segments of MRDV

\begin{tabular}{|c|c|c|c|c|c|c|c|}
\hline \multirow{2}{*}{ No. } & \multirow{2}{*}{ Acc. No. } & \multirow{2}{*}{$\begin{array}{c}\text { Size } \\
\text { nts }\end{array}$} & \multirow{2}{*}{$\begin{array}{c}\begin{array}{c}\mathrm{GC} \\
\text { content }\end{array} \\
\% \\
\end{array}$} & \multicolumn{2}{|c|}{ ORFs } & \multirow{2}{*}{$\begin{array}{l}\mathrm{IR}^{\mathrm{a}} \\
\mathrm{nts}\end{array}$} & \multirow{2}{*}{$\begin{array}{c}5^{\prime} / 3^{\prime}-\text { UTRs }^{b} \\
\text { nts }\end{array}$} \\
\hline & & & & nts & $\mathrm{kDa}$ & & \\
\hline S1 & HQ637550 & 4501 & 32.0 & 4395 & 168.4 & - & $35 / 71$ \\
\hline S2 & HQ637551 & 3813 & 33.2 & 3681 & 141.2 & - & $46 / 86$ \\
\hline S3 & HQ637552 & 3573 & 34.6 & 3441 & 131,8 & - & $14 / 118$ \\
\hline S4 & HQ637553 & 3617 & 30.6 & 3510 & 135.0 & - & $33 / 74$ \\
\hline S5 & HQ637554 & 3164 & 37 & $\begin{array}{c}2814 \\
612\end{array}$ & $\begin{array}{c}106.8 \\
23.5\end{array}$ & - & $15 / 91$ \\
\hline S6 & HQ637555 & 2645 & 37.7 & 2379 & 89.5 & - & $81 / 185$ \\
\hline S7 & HQ637556 & 2193 & 34.4 & $\begin{array}{c}1089 \\
930\end{array}$ & $\begin{array}{l}40.9 \\
36.5\end{array}$ & 52 & $41 / 81$ \\
\hline S8 & HQ637557 & 1936 & 34.7 & 1776 & 67.8 & - & $24 / 136$ \\
\hline S9 & HQ637558 & 1900 & 34.3 & $\begin{array}{c}1044 \\
630\end{array}$ & $\begin{array}{l}39.8 \\
24.1\end{array}$ & 64 & $51 / 111$ \\
\hline S10 & HQ637559 & 1802 & 37.0 & 1677 & 62.9 & - & $22 / 103$ \\
\hline
\end{tabular}

aIR: intergenic regions; ${ }^{\mathrm{b} U T R}$ : untranslated regions. 


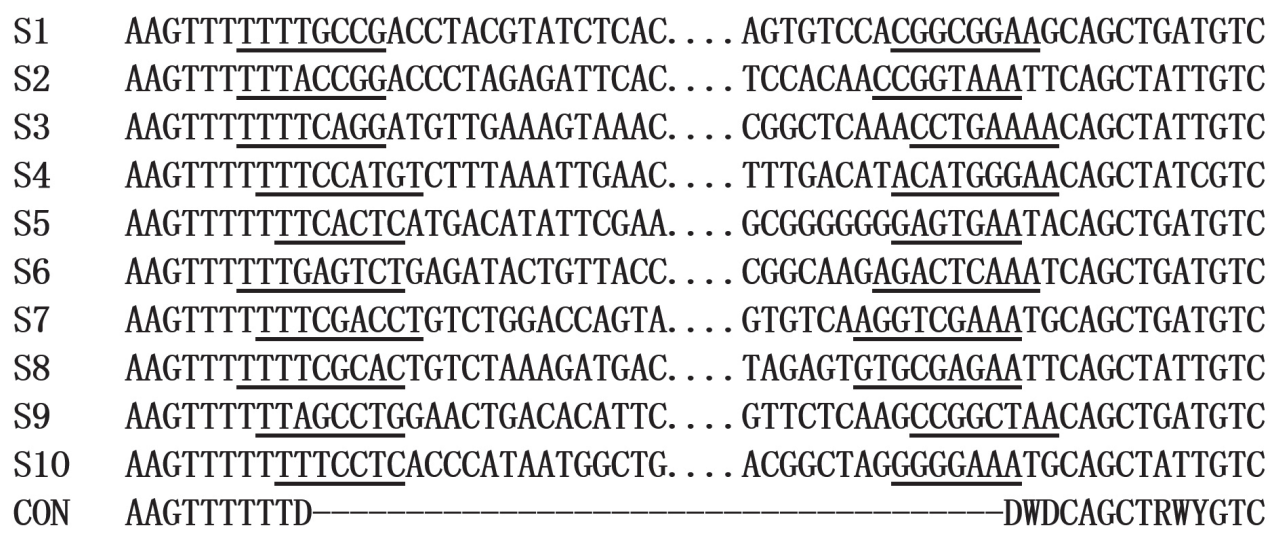

Fig. 2

Multiple alignment of both terminal sequences from each segment of MRDV $\mathrm{CON}$ : consensus sequences $(\mathrm{D}=\mathrm{A}, \mathrm{T}$ or $\mathrm{G} ; \mathrm{R}=\mathrm{A}$ or $\mathrm{G} ; \mathrm{W}=\mathrm{A}$ or $\mathrm{T} ; \mathrm{Y}=\mathrm{T}$ or $\mathrm{C})$.

reovirus genome so far reported. Segments ranged in size from approximately 1.8 to $4.5 \mathrm{~kb}$. Each of the genome segments S1-4, S6, S8 and S10, encoded a single major protein, while S5, S7, and S9 each harbored two non-overlapping or partially overlapping ORFs with different lengths of untranslated regions (UTRs) or intergenic regions (IRs) (Table 1). Thus the MRDV genome encodes at least 13 viral proteins, ranging in calculated molecular weight from approximately 23.5 to $168.4 \mathrm{kDa}$ (Table 1). This is similar to the genomes of other group 2 fijiviruses. All segments had a low GC content (30.6-37.7\%) (Table 1), slightly different from those of other fijiviruses (Zhang et al., 2001; Xue et al., 2014). The extreme $5^{\prime}$ - and 3 '-ends of the sense strand of each segment had a conserved sequence 5'-AAGTTTTTTD. ... DWD CAGCTRWYGTC-3' ( $\mathrm{D}=\mathrm{A}$, $\mathrm{T}$ or $\mathrm{G} ; \mathrm{R}=\mathrm{A}$ or $\mathrm{G} ; \mathrm{W}=\mathrm{A}$ or $\mathrm{T}$; $\mathrm{Y}=\mathrm{T}$ or $\mathrm{C}$ ) (Figure 2), which is similar to the conserved terminal sequences reported from RBSDV, MRCV, and SRBSDV segments (Zhang et al., 2001a; Guzmán et al., 2007; Wang et al., 2010; Xue et al., 2014). A perfect or imperfect 7-9 bp inverted repeat was identified immediately adjacent to the conserved terminal sequences in each genomic segment (Fig. 2). The conserved terminal sequences together

Table 2. Identities between the proteins encoded by genomic segments of MRDV and other fijiviruses

\begin{tabular}{|c|c|c|c|c|c|c|c|c|}
\hline \multirow{3}{*}{$\begin{array}{l}\text { Genome } \\
\text { segment }\end{array}$} & \multirow{3}{*}{ Viral protein } & \multicolumn{6}{|c|}{ Amino acid sequence identities (\%) with other fijiviruses ${ }^{a}$} & \multirow{3}{*}{$\begin{array}{l}\text { Putative } \\
\text { function }\end{array}$} \\
\hline & & \multicolumn{3}{|c|}{ Group 2} & \multirow{2}{*}{$\begin{array}{c}\text { Group } 1 \\
\text { FDV }\end{array}$} & \multirow{2}{*}{$\begin{array}{c}\text { Group } 3 \\
\text { OSDV }\end{array}$} & \multirow{2}{*}{$\begin{array}{c}\text { Group } 5 \\
\text { NLRV }\end{array}$} & \\
\hline & & RBSDV & SRBSDV & MRCV & & & & \\
\hline S1 & P1 & $93.65-94.74$ & $84.34-86.82$ & 78.73 & 64.08 & - & 32.64 & RdRp \\
\hline S2 & P2 & $97.15-97.23$ & $88.17-89.56$ & 84.83 & 58.27 & - & 22.16 & Major core \\
\hline S3 & P3 & $94.68-95.11$ & $84.82-86.82$ & 74.30 & 55.94 & - & 20.83 & Minor core \\
\hline S4 & P4 & $91.36-91.87$ & $72.71-73.65$ & 57.40 & 38.40 & - & 17.69 & Major core \\
\hline \multirow[t]{2}{*}{ S5 } & P5-1 & $89.86-90.50$ & $58.80-59.33$ & 65.45 & 32.90 & - & 18.90 & Viroplasm \\
\hline & P5-2 & $81.28-82.27$ & 68.41-69.05 & 52.71 & - & - & - & Nonstructural \\
\hline S6 & P6 & $84.72-85.61$ & $63.26-64.39$ & 44.20 & 25.03 & - & 17.03 & Viroplasm \\
\hline \multirow[t]{2}{*}{ S7 } & P7-1 & $91.99-92.27$ & $82.63-83.19$ & 59.56 & 53.33 & 32.32 & 20.00 & Tubular \\
\hline & P7-2 & $85.76-87.38$ & $61.81-61.81$ & 44.01 & 27.05 & 14.98 & - & Nonstructural \\
\hline S8 & P8 & 91.54-92.05 & $70.90-71.40$ & 57.87 & 37.59 & 25.84 & 18.72 & Minor core \\
\hline \multirow[t]{2}{*}{ S9 } & P9 & $89.05-90.49$ & $76.95-77.81$ & 62.31 & 35.98 & 25.10 & 15.47 & Viroplasm \\
\hline & & $91.87-94.74$ & $72.73-72.73$ & 60.67 & 39.11 & 21.43 & 21.39 & Nonstructural \\
\hline S10 & P10 & $93.91-94.80$ & $84.92-85.28$ & 72.17 & 48.38 & 32.25 & 20.08 & Major capsid \\
\hline
\end{tabular}

${ }^{a}$ Amino acid sequence identity of MRDV with other fijiviruses, including RBSDV-ZJ (AJ294757, AJ409145-8, AJ297427, AJ297430-1, AJ297433, AJ293984), -AH (HF954985-94), -HeB (KC134289-98), -Hub (AY144568-70, AF521806, AF432355, AY160687, AF397894, AF399826, AF536564, AF227206), -JS (KM921673-82) isolates; SRBSDV-GD (FN563983-8, EU784840-3), -HN (FN563989-96, EU523359-60), -YN( JQ773420-9), -HB (HM585270-9) and -HuN (JQ034348-57) isolates; MRCV (AF499925-8, AF395872-3, AY607586-7, AY923115, DQ023312), FDV (AF049704-5, AF050086, AF356083, AF359556. AY029520-1, AY297693-4, and AY789927), OSDV (AJ583250-1 and AB011026-7), and NLRV (D49693-700, D26127, and D14691). '-' denote no available sequences or no corresponding proteins. 


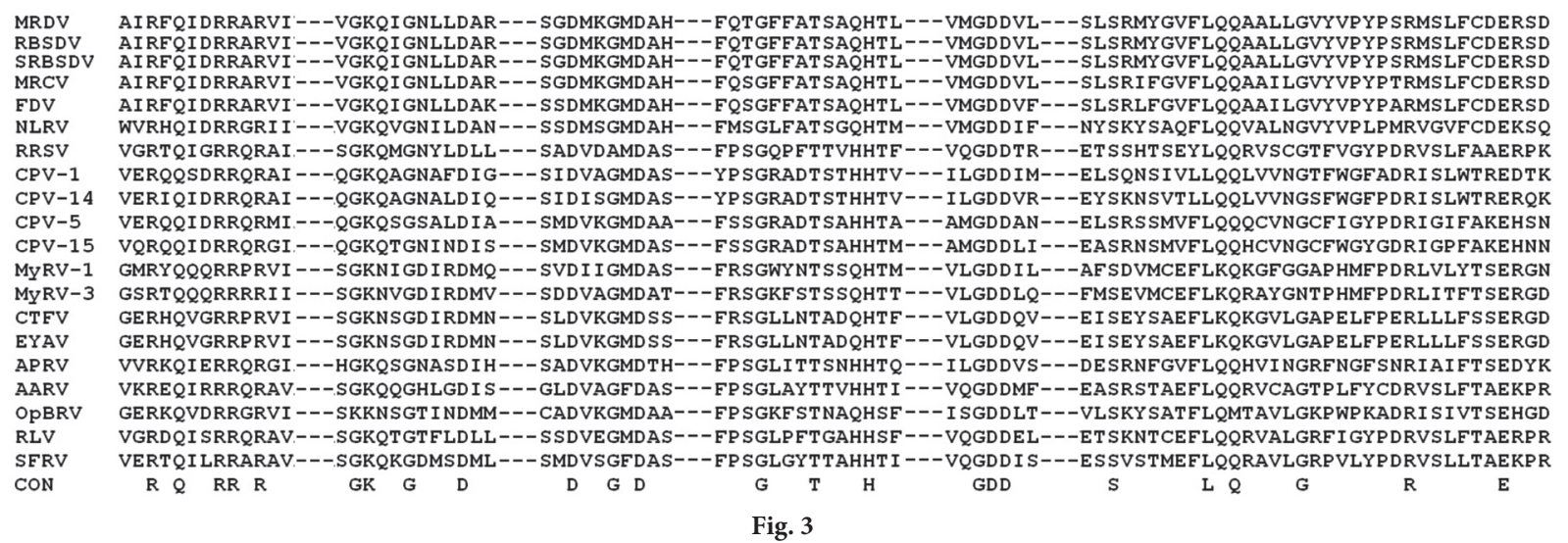

Similarities between MRDV and other reoviruses within the central regions of their RNA-dependent RNA polymerases (RdRPs) The sequences used for comparison were: Rice black-streaked dwarf virus (RBSDV) (AJ294757), SRBSDV (FN563983), Mal de Rio Cuarto virus (MRCV) (AF499925), Fiji disease virus (FDV) (AY029520), and Nilaparvata lugens reovirus (NLRV) (D49693); Rice ragged stunt virus (RRSV) (U66714); Lymantria dispar cypovirus 1 (CPV-1) (AF389463); Lymantria dispar cypovirus 14 (CPV-14), (AF389452); Trichoplusia ni cytoplasmic polyhedrosis virus 15 (CPV-15) (AF291683), Heliothis armigera cypovirus 5 (CPV-5) (EF634323); Cryphonectria parasitica mycoreovirus-1/9B21 (MyRV-1) (AF277888), Rosellinia anti-rot virus (MyRV-3) (AB102674); Colorado tick fever virus Florio N-7180 strain (CTFV) (AF133428), Eyach virus (EYAV) (AF282467); Aedes pseudoscutellaris reovirus (APRV) (DQ087277); Acinopterus angulatus reovirus (AARV) (JN792199); Operophtera brumata reovirus (OpBRV) (DQ192235), Raspberry latent virus (RLV) (HQ012655), Spissistilus festinus reovirus (SFRV) (JF773383); CON: consensus sequences.

with the inverted repeats immediately adjacent to them are thought to be genus-specific and segment-specific signals, respectively, to act as recognition signals for replication and packaging of viral RNAs (Anzola et al., 1987). The similarities amongst conserved terminal sequences of the group 2 fijiviruses suggests that they have similar mechanisms for their replication and packaging.

\section{Sequence comparisons}

Comparisons with the corresponding segments of other fijiviruses showed that MRDV shared 84.3-88.8\%, 67.7$79.0 \%$, and 57.2-76.5\% nucleotide identity with RBSDV, SRBSDV, and MRCV, the other three members of group 2 that have been sequenced. The 13 predicted viral proteins were not only similar in position and size to those found in RBSDV, SRBSDV, and MRCV, but also shared highest identities (81.3-97.2\%, 58.8-89.6\%, 44.0-84.8\%) with them (depending on the protein used for comparison). As expected, MRDV segments were more distantly related (15.0-64.1\%) to the other fijiviruses, including FDV, OSDV, and NLRV (Table 2). The results therefore confirm that MRDV is a member of Fijivirus group 2.

Protein comparisons indicated that the protein P1 with predicted molecular weight of $168 \mathrm{kDa}$ contained the major motifs characteristic for a reoviral RNA-dependent RNA polymerase (RdRp) (Zhang et al., 2007), which can be aligned well with those from other fijiviruses and reoviruses more generally (Fig. 3). Within the second group of the genus Fijivirus, these motifs appeared to be almost identical (Fig. 3), sug- gesting that these viruses have a similar mechanism for viral RNA replication and transcription. In the family Reoviridae, the RdRp is believed to be a minor component of the core particle. This is likely to be the case for MRDV, as an earlier study showed that RdRp activity was associated with purified MRDV particles (Marzachì et al., 1990).

The P1 protein of MRDV was significantly related (22-40\% identity and $39-58 \%$ similarity) to those of Diaphorina citri reovirus (DCRV), an unclassified reovirus (Marutani-Hert et al., 2009), Bloomfield virus, a novel unclassified virus (Webster et al., 2015), Cimodo virus, a novel unclassified virus (Hermanns et al., 2014), Torrey Pines virus, an unclassified Cypovirus (Webster et al., 2015) and Lutzomyia reovirus, a novel unclassified virus (Aguiar et al., 2015). Interestingly, the P8 protein was significantly related to the VP5 of Inachis io cypovirus 2 (KC588370) and VP6 of Mycoreovirus 3 (AB073277) (Fig. 4) and contained the motifs I and II that may be involved in ATP-binding

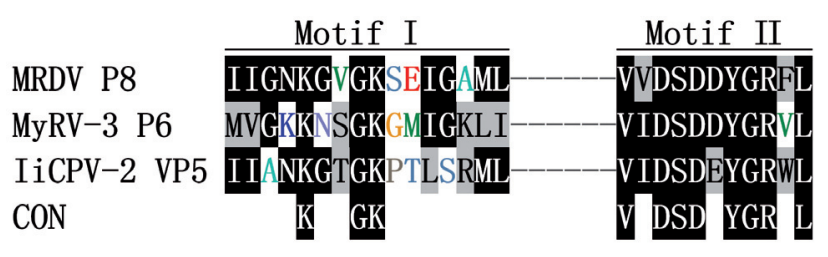

Fig. 4

Conserved motifs that could be involved in ATP-binding activity The sequences used are the VP5 of Inachis io cypovirus 2 (KC588370) and VP6 of Mycoreovirus 3 (AB073277). 


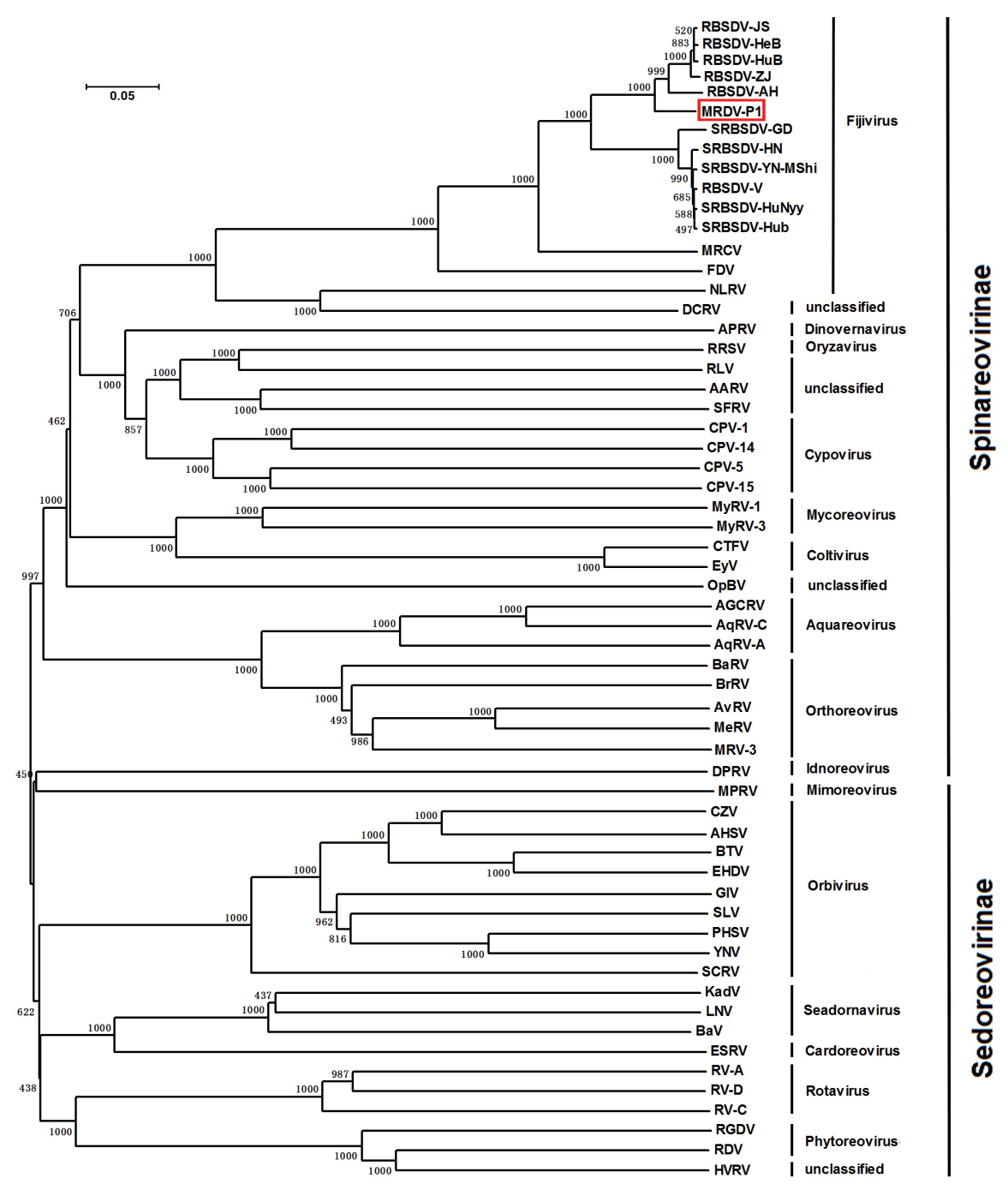

Fig. 5

Phylogenetic tree constructed with MRDV and other reoviral RdRPs

The sequences used for phylogenetic analysis are listed below:

Subfamily Spinareovirinae

Genus Fijivirus: MRDV (in this study), RBSDV-ZJ (AJ294757), -JS (KM921673), -HeB (KC134289), -HuB (AY144568), -AH (HF954985), SRBSDV-GD (FN563983), -HN (FN563989), -YN-MShi (JQ773420), -V (HQ731492), -HuNyy (JQ034348), and -HuB (HM585279), Mal de Rio Cuarto virus (MRCV) (AF499925), Fiji disease virus (FDV) (AY029520), and Nilaparvata lugens reovirus (NLRV) (D49693); genus Oryzavirus: Rice ragged stunt virus (RRSV) (U66714); genus Dinovernavirus: Aedes pseudoscutellaris reovirus (APRV) (DQ087277); genus Cyporeovirus: Lymantria dispar cypovirus 1 (CPV-1) (AF389463), Lymantria dispar cypovirus 14 (CPV-14) (AF389452), Heliothis armigera cypovirus 5 (CPV-5) (EF634323), Trichoplusia ni cytoplasmic polyhedrosis virus 15 (CPV-15) (AF291683); genus Mycoreovirus: Cryphonectria parasitica mycoreovirus-1/9B21 (MyRV-1) (AF277888), Rosellinia anti-rot virus (MyRV-3) (AB102674); genus Coltivirus: Colorado tick fever virus Florio N-7180 strain (CTFV) (AF133428), Eyach virus (EYAV) (AF282467); genus Aquareovirus: American-grass-carp-reovirus (AGCRV) (EF589099), Aquareovirus C (AqRV-C) (AF403399), Aquareovirus A (AqRV-A) (AF418295); genus Orthoreovirus: Baboon orthoreovirus (BaRV) (HQ847904), Broome virus (BrRV) (GQ258979), Avian orthoreovirus (AvRV) (FR694192), Melaka orthoreovirus (MeRV) (JF342661), Mammalian orthoreovirus 3-1 (MRV-3-1) (GQ468266); genus Idnoreovirus: Diadromus pulchellus reovirus (DpRV) (X80481).

\section{Subfamily Sedoreovirinae}

Genus Mimoreovirus: Micromonas pusilla reovirus (MPRV) (DQ126102); genus Orbivirus: Chuzan virus (CZV) (AB018086), African horse sickness virus (AHSV) (U94887), Blue tongue virus (BTV) (X12819), Epizootic hemorrhagic disease virus (EHDV) (AM744977), Great Island virus (GIV) (HM543465), Stretch Lagoon orbivirus (SLV) (EU718676), Peruvian horse sickness virus (PHSV) (DQ248057), Yunnan orbivirus (YNV) (AY701509), St Croix River virus (SCRV) (AF133431); genus Seadornavirus: Kadipiro virus (KadV) (AF133429), Liao ning virus (LNV) (AY701339), Banna virus (BaV) (AF133430); genus Cardoreovirus: Eriocheir sinensis reovirus (ESRV) (AY542965); genus Rotavirus: Rotavirus A (RV-A) (DQ838640), Rotavirus D (RV-D) (GU733443), Rotavirus C (RV-C) (AJ304859); genus Phytoreovirus: Rice gall dwarf virus (RGDV) (AB254451), Rice dwarf virus (RDV) (U73201).

Unassigned Reoviridae

Diaphorina citri reovirus (DCRV) (AB458510), Raspberry latent virus (RLV) (HQ012655), Acinopterus angulatus reovirus (AARV) (JN792199), Spissistilus festinus reovirus (SFRV) (JF773383), Operophtera brumata reovirus (OpBRV) (DQ192235), Homalodisca vitripennis reovirus (HVRV) (FJ497789). 
activity (Zhang et al., 2008). The P2 protein encoded by S2 of MRDV, a putative major core capsid protein, appeared to be the most conserved viral protein among the members of group 2 fijiviruses (Table 2), suggesting that the conservation provides the structural basis for similar morphology and replication mechanism of this group of viruses. However, the viral proteins encoded on S2-S7 and S9-S10 did not exhibit any significant sequence similarity to other reoviral (or other viral) proteins except those of fijiviruses. On the basis of these similarities, putative functions and structures can be assigned to the predicted MRDV proteins (Table 2).

\section{Phylogenetic analysis}

To determine the appropriate taxonomic position of MRDV, the new sequences were further used in phylogenetic analysis. The protein $\mathrm{P} 1(\mathrm{RdRp})$ is the only protein that can be used for establishing substantial (if relatively distant) relationships between different genera within the family Reoviridae. In the phylogenetic tree (Fig. 5) constructed with reoviral RdRps by the UPGMA method, two sub-families, fifteen genera and some unclassified members of the family Reoviridae were separated by branches supporting the virus taxonomy in the Ninth report of ICTV (Attoui et al., 2012). The known members of the genus Fijivirus form a mono- phyletic branch, within which MRDV, RBSDV, SRBSDV, and MRCV cluster closely together. Of the four viruses causing rough dwarf disease, MRCV is known only from Argentina, South America, and appears to be somewhat distant from other three viruses, reflecting its geographic isolation, but MRDV (from Europe) appeared to be closer to RBSDV than was SRBSDV, although RBSDV and SRBSDV are both known from East Asia. This suggests that MRDV and RBSDV might best be considered geographic strains of a single species.

A phylogenetic tree of the highly conserved major capsid proteins of fijiviruses (Fig. 6) confirmed this pattern of grouping within the genus. Group 2 fijiviruses formed a distinct group, within which all known MRDV and RBSDV isolates were clustered in a distinct clade well-separated from all known MRCV and SRBSDV isolates. Phylogenetic trees using the other corresponding segments of all known fijivruses had a similar pattern of branching and relationships (data not shown).

The conserved terminal sequences of reoviral genome segments also have taxonomic significance (McMahon et al., 1999). The terminal sequences of MRDV are almost identical to those of RBSDV, slightly different from those from SRBSDV, MRCV, and FDV, and obviously distant from those of OSDV and NLRV, although all fijiviruses share the consensus (5'-A.....GTC-3') (Fig. 7a). When the terminal sequences were used to construct a phylogenetic

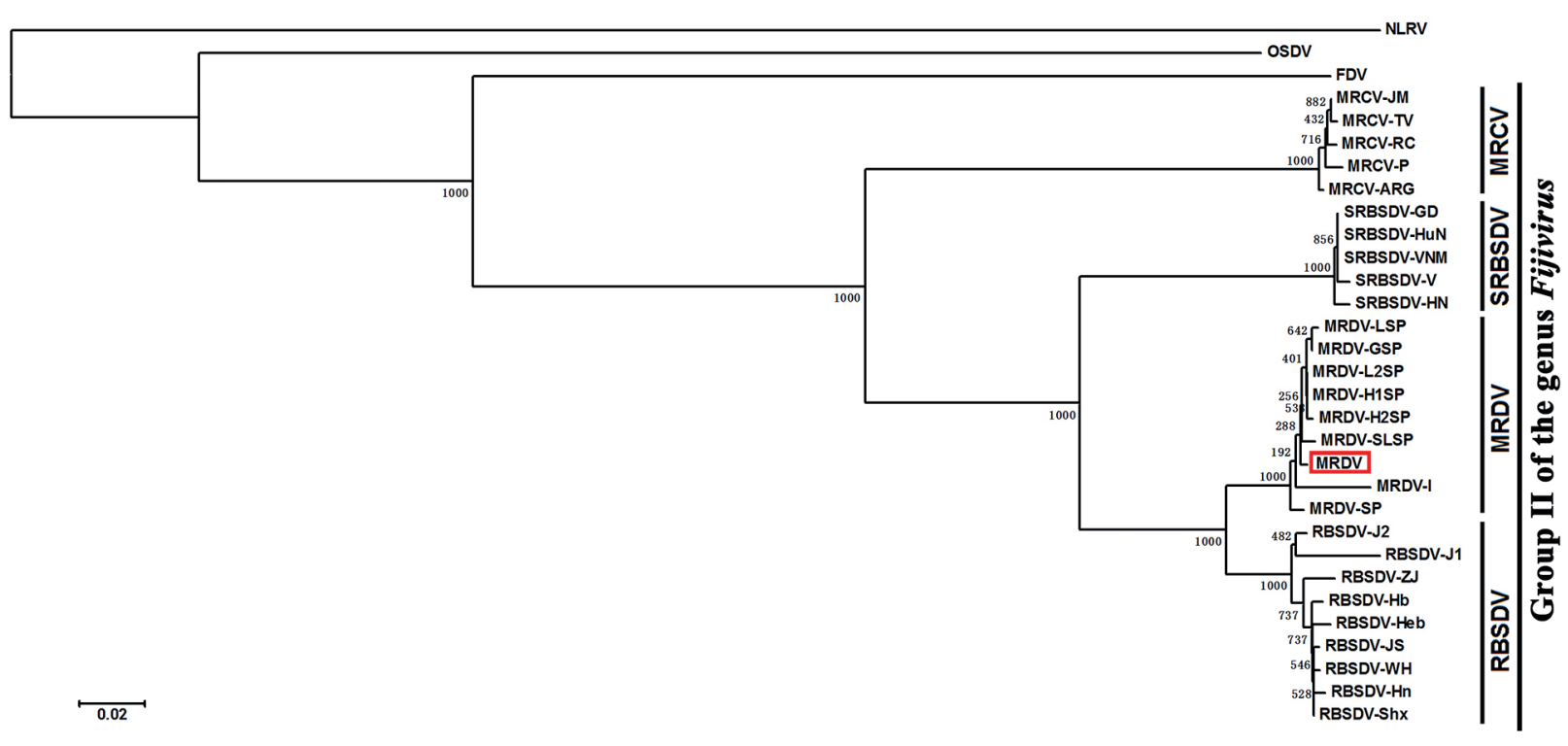

Fig. 6

Phylogenetic tree constructed with MRDV (from this study) and other known fijiviral major capsid proteins

The sequences used for phylogenetic analysis were: NLRV (D26127); OSDV (AB011025); FDV (AY297694); MRCV-JM (AY999338), -TV (AY999339), -RC (AY999337), -P (AY999340), -ARG (AY607586); SRBSDV-GD (EU784840),-HuN (JQ034357), -VNM (JQ692581), -V (HQ731501), -HN (EU523360); MRDV-LSP (LK392325), -GSP (LK392328), -L2SP (LK392330), -H1SP (LK392326), -H2SP (LK392327), -SLSP (LK392329), -I (L76560), -Sp (JQ975001); RBSDV-J1 (D00606), -J2 (GU322365), -ZJ (AJ297433), -Hb (AF227205), -Heb (AJ297434), -JS (AY039835), -WH (AJ291707), -Hn (AF227207), -Shx (AF227208). 
(a)

\begin{tabular}{|c|c|}
\hline MRDV & 5' - AAGTTTTTTDN- VDWDCAGCTRWYGTC -3' \\
\hline RBSD & 5' - AAGTTTTTTDN- - VDWDCAGCTRHYGTC -3, \\
\hline & 5' - AAGTTTTTWDV--VDWNCAGCTRWYGTC -3' \\
\hline MRCV & 5' - AAGTTTTTWNN--VDWDCAGCTRWYGTC -3' \\
\hline & 5' - AAGTTTTTWHV---NWDHCAGCWRRYGTC -3' \\
\hline & 5' - AACGAAAAAAA- - SVSTTTTTTTTAGTC -3' \\
\hline & 5' - AGTHHNHNNH - VNNNNHVHWGTTGTC -3' \\
\hline
\end{tabular}

(b)

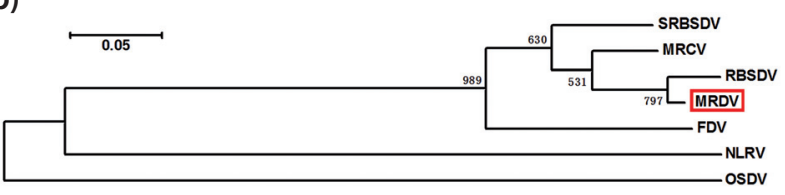

Fig. 7

Multiple alignment (a) and phylogenetic tree (b) of the conserved terminal sequences (positive strand) of fijivirus genome segments $\mathrm{N}=\mathrm{A}, \mathrm{T}, \mathrm{C}$ or $\mathrm{G} ; \mathrm{V}=\mathrm{A}, \mathrm{C}$ or $\mathrm{G} ; \mathrm{H}=\mathrm{A}, \mathrm{C}$ or $\mathrm{T} ; \mathrm{D}=\mathrm{A}, \mathrm{T}$ or $\mathrm{G} ; \mathrm{R}=\mathrm{A}$ or $\mathrm{G}$; $\mathrm{W}=\mathrm{A}$ or $\mathrm{T} ; \mathrm{Y}=\mathrm{T}$ or $\mathrm{C}$.

tree, MRDV closely clustered with RBSDV in a single branch (Fig. 7b). These results consistently support the hypothesis that MRDV and RBSDV should be considered geographic strains of a single species.

\section{Discussion}

The complete genomic S1-S10 sequences of an Italian isolate of MRDV have been determined and are clearly homologous to those of RBSDV. During the preparation of this manuscript, the partial S1-S10 genomic sequences of a Spanish isolate of MRDV were also made public (accession numbers LK392325-LK392343; Achon et al., 2015). The Italian and Spanish isolates share more than 95\% identities with each other at both the nucleotide and amino acid levels and S7-S10 of both isolates share $95.6-99.7 \%$ nucleotide and amino acid identities with the partial sequences of the isolates previously described by Marzachi et al. $(1991,1995)$, although those earlier sequences appear to be wrongly labelled: those labelled S6 and S7 should be reassigned as S7 and S8, respectively, as first proposed by Isogai et al. (1995) on the basis of hybridization experiments.

According to the current species demarcation criteria for the genus Fijivirus (Attoui et al., 2012), isolates of the same species may be identified by sequence analysis ( $>40 \%-55 \%$ nucleotide or amino acid identity in comparisons of homologous proteins or genomic segments), cross-hybridization of less conserved genome segments, serological cross-reactions, and similarities in host range and vector. Here, nucleotide sequence analysis showed that all genome segments of MRDV had more than $84 \%$ identity with those of RBSDV and always less than $80 \%$ identity with those of SRBSDV and MRCV, while the corresponding values for protein comparisons were respectively $>81 \%$ and $<75 \%$. Such comparisons are intrinsically more reliable than results of cross hybridization previously used to examine differences between these viruses (Isogai et al., 1995; Marzachi et al., 1995), which can be influenced by many external factors and are not so reliably quantified. Although those methods had suggested that MRDV and RBSDV might be classified into different species, the sequence data show that most homologous viral proteins of MRDV and RBSDV have more than $90 \%$ amino acid identity and in P2, a core structural protein, values are more than $97 \%$.

The experimental host ranges of MRDV and RBSDV, where compared, are similar. It is true that MRDV does not naturally infect rice whereas RBSDV naturally infects both rice and maize, but these differences may partly result from the crop varieties used. In addition, both viruses are naturally transmitted by the small brown planthopper, Laodelphax striatellus Fallén, in a persistent manner. We suggest that more evidence is needed to support the claim that the vector can transmit MRDV through its eggs to a small proportion (4\%) of the offspring (Harpaz and Klein, 1969; Milne et al., 1977a), while all other fijiviruses are not transmitted via eggs.

Taken together, these comparisons and considerations strongly suggest that MRDV and RBSDV should be regarded as geographic strains of a single species. Since both viruses cause similar symptoms on a range of cereal plants, we tentatively suggest Cereal black-streaked dwarf fijivirus (CBSDV) as a name for the species.

Acknowledgement. This work was funded by National Science and Technology Support Program (2012BAD19B03), the Zhejiang Provincial Science and Technology Project (2010C12027), and the Innovation Foundation from our Academy (2015-cxzt-14). We thank Dr. Piero Caciagli, Istituto di Virologia Vegetale - CNR, Torino, Italy, for generously providing maize plant samples infected by MRDV, and Professor M. J. Adams, Stevenage, UK for help in correcting the English of the manuscript.

\section{References}

Achon MA, Subira J, Sin E (2013): Seasonal occurrence of Laodelphax striatellus in Spain: Effect on the incidence of Maize rough dwarf virus. Crop Prot. 47, 1-5. https://doi. org/10.1016/j.cropro.2013.01.002

Achon MA, Serrano L, Sabater J, Porta C (2015): Understanding the epidemiological factors that intensify the incidence of maize rough dwarf disease in Spain. Ann. Appl. Biol. 166, 311-320. https://doi.org/10.1111/aab.12184

Aguiar ER, Olmo RP, Paro S, Ferreira FV, de Faria IJ, Todjro YM, Lobo FP, Kroon EG, Meignin C, Gatherer D, Imler JL, 
Marques JT (2015): Sequence-independent characterization of viruses based on the pattern of viral small RNAs produced by the host. Nucleic Acids Res. 43, 6191-6206. https://doi.org/10.1093/nar/gkv587.

Ali F, Yan J (2012): Disease resistance in maize and the role of molecular breeding in defending against global threat. J. Integr. Plant Biol. 54, 134-151. https://doi.org/10.1111/ j.1744-7909.2012.01105.x

Altschul SF, Madden TL, Schaffer AA, Zhang J, Zhang Z, Miller W, Lipman DJ (1997): Gapped BLAST and PSI-BLAST: a new generation of protein database search programs. $\mathrm{Nu}-$ cleic Acids Res. 25, 3389-3402. https://doi.org/10.1093/ nar/25.17.3389

Anzola JV, Xu Z, Asamizu T, Nuss DL (1987): Segment-specific inverted repeats found adjacent to conserved terminal sequences in wound tumour virus genome and defective interfering RNAs. Proc. Natl. Acad. Sci. USA 84, 8301-8305. https://doi.org/10.1073/pnas.84.23.8301

Attoui H, Mertens PPC, Becnel J, Belaganahalli S, Bergoin M, Brussaard CP, Chappell JD, Ciarlet M, del Vas M, Dermody TS, Dormitzer PR, Duncan R, Fcang Q, Graham R, Guglielmi KM, Harding RM, Hillman B, Makkay A, Marzachì C, Matthijnssens J, Milne RG, Mohd Jaafar F, Mori H, Noordeloos AA, Omura T, Patton JT, Rao S, Maan M, Stoltz D, Suzuki N, Upadhyaya NM, Wei C, Zhou H (2012): Family Reoviridae. In King AMQ, Adams MJ, Carstens EB, Lefkowitz EJ (Eds): Virus Taxonomy: Classification and Nomenclature of Viruses. Ninth Report of the International Committee on Taxonomy of Viruses, Academic Press, London and San Diego, pp. 541-637.

Azuhata F, Uyeda I, Kimura I, Shikata E (1993): Close similarity between genome structures of rice black-streaked dwarf and maize rough dwarf viruses. J. Gen. Virol. 74, 1227-1232. https://doi.org/10.1099/0022-1317-74-7-1227

Boccardo G, Milne RG (1984): Plant reovirus group. CMI/AAB Descriptions of Plant Viruses, Mo. 294.

Distéfano AJ, Conci LR, Mu-oz Hidalgo M, Guzmán FA, Hopp HE, del Vas M (2003): Sequence and phylogenetic analysis of genome segments S1, S2, S3 and S6 of Mal de Río Cuarto virus, a newly accepted Fijivirus species. Virus Res. 92, 113-121. https://doi.org/10.1016/S0168-1702(02)00325-8

Distéfano AJ, Conci LR, Mu-oz Hidalgo M, Guzmán FA, Hopp HE, del Vas M (2002): Sequence analysis of genome segments S4 and S8 of Mal de Río Cuarto virus (MRCV): evidence that the virus should be a separate Fijivirus species. Arch. Virol. 147, 1699-1709. https://doi.org/10.1007/ s00705-002-0840-4

Distéfano AJ, Hopp HE, del Vas M (2005): Sequence analysis of genome segments $\mathrm{S} 5$ and $\mathrm{S} 10$ of Mal de Rio Cuarto virus (Fijivirus, Reoviridae). Arch. Virol. 150, 1241-1248. https://doi.org/10.1007/s00705-004-0477-6

Distéfano AJ, Maldonado S, Hopp HE, del Vas M (2009): Mal de Río Cuarto virus (MRCV) genomic segment $\mathrm{S} 3$ codes for the major core capsid protein. Virus Genes 38, 455-460. https://doi.org/10.1007/s11262-009-0345-2

Dovas CI, Eythymiou K, Katis NI (2004): First report of maize rough dwarf virus (MRDV) on maize crops in Greece.
Plant Pathol. 53, 238. https://doi.org/10.1111/j.00320862.2004.00973.x

Dulieu P, Bar-Joseph M (1989): Rapid isolation of double stranded RNA segments from disulphide crosslinked polyacrylamide gels. J. Virol. Methods 24, 77-84. https://doi. org/10.1016/0166-0934(89)90009-8

Guzmán FA, Distefano AJ, Arneodo JD, Hopp HE, Lenardon SL, del Vas M, Conci LR (2007): Sequencing of the bicistronic genome segments S7 and S9 of Mal de Río Cuarto virus (Fijivirus, Reoviridae) completes the genome of this virus. Arch. Virol. 152, 565-573. https://doi.org/10.1007/ s00705-006-0864-2

Harpaz I, Klein M (1969): Vector-induced modifications in a plant virus. Entom. Exp. Appl. 12, 99-106. https://doi. org/10.1111/j.1570-7458.1969.tb02502.x

Harpaz I (1972): Maize Rough Dwarf. A planthopper virus disease affecting maize, rice, small grains and grasses. Israel University Press, Jerusalem.

Hermanns K, Zirkel F, Kurth A, Drosten C, Junglen S (2014): Cimodo virus belongs to a novel lineage of reoviruses isolated from African mosquitoes. J. Gen. Virol. 95, 905-909. https://doi.org/10.1099/vir.0.062349-0

Hoang TA, Zhang HM, Yang J, Chen JP, Hébrard E, Zhou GH, Ngo VV, Cheng JA (2011): Identification, characterization, and distribution of Southern rice black-streaked dwarf virus in Vietnam. Plant Dis. 95, 1063-1069. https://doi. org/10.1094/PDIS-07-10-0535

Isogai M, Azuhata F, Uyeda I, Shikata E, Kimura I (1995): Genomic relationships between rice black-streaked dwarf and maize rough dwarf Fijiviruses detected by nucleic acid hybridization. Ann. Phytopath. Soc. Japan 61, 513-518. https://doi.org/10.3186/jjphytopath.61.513

Lenardon SL, Giolitti F, Welz HG, Verma P (2001): Occurrence of a Reovirus Infecting Maize in India. Plant Dis. 85, 99. https://doi.org/10.1094/PDIS.2001.85.1.99A

Lenardon SL, March GJ, Nome SF, Ornaghi JA (1998): Recent Outbreak of "Mal de Rio Cuarto" Virus on Corn in Argentina. Plant Dis. 82, 448. https://doi.org/10.1094/ PDIS.1998.82.4.448C

Librado P, Rozas J (2009): DnaSP v5: A software for comprehensive analysis of DNA polymorphism data. Bioinformatics 25, 1451-1452. https://doi.org/10.1093/bioinformatics/ btp187

Luisoni E, Lovisoro O, Kitagawa Y, Shikata E (1973): Serological relationship between maize rough dwarf virus and rice black-streaked dwarf virus. Virology 53, 281-283. https:// doi.org/10.1016/0042-6822(73)90416-9

Marutani-Hert M, Hunter WB, Katsar CS, Sinisterra XH, Hall DG, Powell CA (2009): Reovirus-Like Sequences Isolated from Adult Asian Citrus Psyllid, (Hemiptera: Psyllidae: Diaphorina citri). Fla. Entomol. 92, 314-320. https://doi. org/10.1653/024.092.0216

Marzachì C, Accotto GP, d'Aquilio M, Caciagli P, Boccardo G (1990): In vitro transcription of the double-stranded RNA genome of maize rough dwarf virus (Reoviridae). J. Gen. Virol. 71, 707-711. https://doi.org/10.1099/0022$\underline{1317-71-3-707}$ 
Marzachi C, Boccardo G, Nuss DL (1991): Cloning of the maize rough dwarf virus genome: molecular confirmation of the plant-reovirus classification scheme and identification of two large nonoverlapping coding domains within a single genomic segment. Virology 180, 518-526. https://doi. org/10.1016/0042-6822(91)90065-I

Marzachi C, Boccardo G, Milne RG, Isogai M, Uyeda I (1995): Genome structure and variability of Fijiviruses. Sem. Virol. 6, 103-108. https://doi.org/10.1006/smvy.1995.0013

Matsukura K, Towata T, Sakai JI, Onuki M, Okuda M, Matsumura M (2013): Dynamics of Southern rice black-streaked dwarf virus in rice and implication for virus acquisition. Phytopathol. 103, 509-512. https://doi.org/10.1094/ PHYTO-10-12-0261-R

McMahon JA, Dale JL, Harding RM (1999): Taxonomic implications for Fijiviruses based on the terminal sequences of Fiji disease fijivirus. Arch. Virol. 144, 2259-2263. https:// doi.org/10.1007/s007050050641

Milne RG, Boccardo G, Elena Dal B, Nome F (1983): Association of Maize Rough Dwarf Virus with Mal de Rio Cuarto in Argentina. Phytopathol. 73, 1290-1292. https://doi. org/10.1094/Phyto-73-1290

Milne RG, Conti M, Lisa V (1973): Partial purification, structure and infectivity of complete maize rough dwarf virus particles. Virology 53, 130-141. https://doi.org/10.1016/00426822(73)90472-8

Milne RG, Lovisolo O (1977a): Maize rough dwarf and related viruses. Adv. Virus Res. 21, 267-341. https://doi.org/10.1016/ $\underline{\text { S0065-3527(08)60764-2 }}$

Milne RG, Luisoni E (1977b): Serological relationships among maize rough dwarf-like viruses. J. Virol. 80, 12-20. https:// doi.org/10.1016/0042-6822(77)90377-4

Ortiz V, Betbese Lucas J, Lopez Querol A, Romero J (2014): Detection of Maize rough dwarf virus in Spain: a survey of susceptible host genotypes and molecular characterization of two genomic segments of the virus. Phytopath. Med. 53, 40-53.

Reddy DVR, Shikata E, Boccardo G, Black L (1975): Coelectrophoresis of double-stranded RNA from maize rough dwarf and rice black-streaked dwarf viruses. Virology 67, 279-282. https://doi.org/10.1016/0042-6822(75)90425-0

Sambrook J, Fritsch EF, Maniatis T (1989): Molecular cloning: a laboratory manual. Cold Spring Harbor Laboratory Press, NewYork.

Tamura K, Peterson D, Peterson N, Stecher G, Nei M, Kumar $S$ (2011): MEGA5: molecular evolutionary genetics analysis using maximum likelihood, evolutionary distance, and maximum parsimony methods. Mol. Biol. Evol. 28, 2731-2739. https://doi.org/10.1093/molbev/msr121

Thompson JD, Higgins DG, Gibson TJ (1994): CLUSTALW: improving the sensitivity of progressive multiple sequence alignment through sequence weighting, positions-specific gap penalties and weight matrix choice. Nucleic Acids Res. 22, 4673-4680. https://doi.org/10.1093/nar/22.22.4673

Uyeda I, Bong-Choon L, Ando Y (1998): Reovirus isolation and RNA extraction. In Foster GD, Taylor SC (Eds): Methods in molecular biology. Vol 81. Plant virology protocols: from virus isolation to transgenic resistance. Human Press, Totowa, pp. 65-75 https://doi.org/10.1385/089603-385-6:65

Wang Q, Yang J, Zhou GH, Zhang HM, Chen JP, Adams MJ (2010): The complete genome sequence of two isolates of a new rice-infecting fijivirus from China. J. Phytopathol. 158, 733-737. https://doi.org/10.1111/j.1439-0434 $.2010 .01679 . \mathrm{x}$

Webster CL, Waldron FM, Robertson S, Crowson D, Ferrari G, Quintana JF, Brouqui JM, Bayne EH, Longdon B, Buck AH, Lazzaro BP, Akorli J, Haddrill PR, Obbard DJ (2015): The Discovery, Distribution, and Evolution of Viruses Associated with Drosophila melanogaster. PLoS Biol. 13, e1002210. https://doi.org/10.1371/journal.pbio.1002210

Wu WQ, Guo XG, Zhang HM, Yang J, Lv MF, Chen JP (2013): Simultaneous Detection and Survey of Three Rice Viruses in China. Plant Dis. 97, 1181-1186. https://doi.org/10.1094/ PDIS-02-12-0207-RE

Xue J, Li J, Zhang HM, Yang J, Lv MF, Gao BD, Chen JP (2014): Molecular Characterization of Southern Rice BlackedStreaked Dwarf Virus (SRBSDV) from Vietnam. J. Phytopathol. 162, 349-358. https://doi.org/10.1111/ jph.12196

Yin X, Xu F, Zheng F, Li X, Liu B, Zhang C (2011): Molecular Characterization of Segments S7 to S10 of a Southern Rice Black-streaked Dwarf Virus Isolate from Maize in Northern China. Virol. Sin. 26, 47-53. https://doi. org/10.1007/s12250-011-3170-9

Zhang HM, Chen JP, Adams MJ (2001a): Molecular characterization of segments 1 to 6 of rice black-streaked dwarf virus from China provides the complete genome. Arch. Virol. 146, 2331-2339. https://doi.org/10.1007/s007050170006

Zhang HM, Chen JP, Lei JL, Adams MJ (2001b): Sequence analysis shows that a dwarfing disease on rice, maize and wheat in China is caused by Rice black-streaked dwarf virus (RBSDV). Eur. J. Plant Pathol. 107, 563-567. https://doi. org/10.1023/A:1011204010663

Zhang HM, Yang J, Chen JP, Adams MJ (2008): A black-streaked dwarf disease on rice in China is caused by a novel fijivirus. Arch. Virol. 153, 1893-1898. https://doi.org/10.1007/ s00705-008-0209-4

Zhang HM, Yang J, Xin X, Chen JP, Adams MJ (2007a): Molecular characterization of the genome segments S4, S6 and S7 of rice gall dwarf virus. Arch. Virol. 152, 1593-1602. https:// doi.org/10.1007/s00705-007-1004-3

Zhang HM, Yang J, Xin X, Chen JP, Adams MJ (2007b): Molecular characterization of the largest and smallest genome segments, $\mathrm{S} 1$ and S12, of rice gall dwarf virus. Virus Genes 35, 815-823. https://doi.org/10.1007/s11262-007-0142-8

Zhou GH, Wen JJ, Cai DJ, Li P, Xu DL, Zhang SG (2008): Southern rice black-streaked dwarf virus: A new proposed Fijivirus species in the family Reoviridae. Chin. Sci. Bull. 53, 3677-3685. https://doi.org/10.1007/s11434008-0467-2 